\title{
Pelatihan Pencatatan Keuangan Sederhana untuk Menumbuhkan Kepedulian Menabung pada Anak-Anak Pesisir Dalam di Desa Bonde, Kecamatan Pamboang, Kabupaten Majene
}

\section{Simple Financial Recording Training to Foster Savings Concern for Coastal Children in Bonde Village, Pamboang District, Majene Regency}

\author{
Nurhidayah ${ }^{*}$, Dahlia
}

Prodi Akuntansi Fakultas Ekonomi Universitas Sulawesi Barat, Jl. Prof. Dr. Baharuddin Lopa SH, Talumung, Kabupaten Majene, Sulawesi Barat, Indonesia

\begin{tabular}{l}
\hline Info Artikel \\
\hline Diterima 04 Nopember 2019 \\
Ditelaah 14 Nopember 2019 \\
Disetujui 10 Desember 2019 \\
Tersedia daring 31 Desember \\
2019 \\
*Penulis untuk korespondensi \\
nurhidayah@unsulbar.ac.id \\
\hline \\
Kata Kunci: \\
Ayo menabung, \\
jurnal keuangan anak, \\
anak-anak
\end{tabular}

Keywords:

Come on saving,

Children's financial journal,

Child

\section{ABSTRAK}

Program pengabdian kepada masyarakat ini bertujuan untuk menumbuhkan kepedulian dan motivasi menabung sejak dini, membedakan antara kebutuhan dan keinginan serta memberi pemahaman mengenai pencatatan keuangan sederhana. Pelaksanaan kegiatan dalam bentuk pelatihan pencatatan keuangan harian sederhana dilaksanakan di Aula Pertemuan Kantor Desa Bonde. Pendampingan juga dilaksanakan sebagai kelanjutan dari pelatihan melalui modul pencatatan keuangan sederhana untuk transaksi-transaksi harian yang umum dilakukan oleh anak-anak. Modul diberikan pada saat pelaksaan pelatihan dan pendampingan ini dilakukan pada salah satu rumah warga Desa Bonde yaitu di Dusun Tappa Banua yang merupakan area pesisir Desa Bonde. Hasil dari program pengabdian ini berdasarkan hasil penilaian sejak pelatihan hingga hari terakhir pendampingan menunjukkan bahwa 70\% anak-anak Desa Bonde sudah memahami tentang pencatatan keuangan sederhana terhadap transaksi harian yang biasa dilakukan oleh anak-anak dan sudah memulai untuk menabungkan sebagian uang jajan yang diberikan oleh orang tua/wali. Sebagian lainnya sudah memahaminya namun belum termotivasi untuk menabung sejak dini.

\section{ABSTRACT}

\begin{abstract}
This community service program was aimed to foster awareness and motivation to save early on and to understand the distinction between needs and desires through simple financial records. The training of the simple daily financial recording was carried out in the Meeting Room of Bonde Village Office. Mentoring was also carried out as a continuation of previous training through a simple financial recording module for daily transactions that are commonly carried out by children. The module was given when the training. The mentoring was carried out in one of the houses of Bonde Village residents in Tappa Banua Hamlet, which is a coastal area of Bonde Village. The results of the assessment from the training until the last day of mentoring showed that $70 \%$ of Bonde village children had understood the simple financial recording of daily transactions that are usually done by children, and they have started to save some of the allowance given by parents/guardians. Others have understood it but have not been motivated to save from an early age.
\end{abstract}

ISSN 2685-0354 (Media Online). Diterbitkan oleh Universitas Prof. Dr. Hazairin, SH. Ini merupakan jurnal bebas akses di bawah lisensi Creative Commons Atribution 4.0 International (https://creativecommons.org/licenses/by/4.0

\section{PENDAHULUAN}

Pamboang adalah salah satu kecamatan yang ada di Kabupaten Majene. Luas wilayah Kecamatan Pamboang adalah 70,19 $\mathrm{km}^{2}$ atau 7,41\% dari keseluruhan wilayah Kabupaten Majene. Jarak tempuh dari Kota Majene ke Kecamatan Pamboang adalah sekitar 30 menit. Kecamatan ini memiliki 22.626 jiwa penduduk dengan 4.543 rumah tangga. Salah satu desa dari 15 desa yang ada di wilayah kecamatan ini adalah Desa Bonde. Desa Bonde merupakan 
daerah pesisir Kecamatan Pamboang yang memiliki \pm 180 anak-anak. Desa ini terdiri dari 4 dusun yaitu Dusun Luaor, Dusun Soppeng Jawa, Dusun Tappa Banua dan Dusun Alle-alle (Badan Pusat Statistik Kabupaten Majene, 2018).

Hasil observasi di lokasi kegiatan melalui wawancara dengan aparat desa dan beberapa masyarakat Desa Bonde menggambarkan bahwa masyarakat setempat (termasuk anak-anak umur sekolah) tergolong konsumtif. Anak-anak pada umumnya lebih mementingkan faktor keinginan dibandingkan kebutuhan sehingga menambah permasalahan ekonomi di dalam keluarga. Hal ini disebabkan oleh kurangnya pemahaman perbedaan antara kebutuhan dan keinginan. Sebagian besar anak-anak juga belum menyadari tingkat kesulitan ekonomi orang tua yang sebagian besar berprofesi sebagai nelayan.

Berkonsumsi merupakah hal yang wajar. Namun, berkonsumsi secara berlebihan akan melahirkan gaya hidup konsumtif bahkan menjadi budaya konsumtif. Menurut Anggreini dan Mariyanti (2014), perilaku konsumtif dapat digolongkan sebagai perilaku kenakalan atau perilaku menyimpang jika anak-anak berbelanja dari uang yang diperoleh dengan cara membohongi orang tua atau menjual barang-barang berharga untuk berbelanja atau bahkan mencuri uang orang tua.

Budaya konsumtif tidak hanya untuk makanan, akan tetapi juga dalam konteks yang sangat luas misalnya pemakaian listrik dan air secara berlebihan atau penggunaan pulsa dan paket data yang berlebihan. Oleh karena itu, seringkali ada kerancuan antara kebutuhan dan keinginan. Pemakaian berlebihan menjadi awal yang menimbulkan ketergantungan. Dalam konteks anak-anak, kebanyakan gaya hidup konsumtif berawal dari jajan yang berlebihan. Salah satu usaha yang dapat ditempuh untuk meminimalkan gaya hidup yang konsumtif di kalangan anak-anak adalah meningkatkan kesadaran anak-anak tentang literasi keuangan terutama perbedaan antara kebutuhan dan keinginan dengan tujuan menabung uang sisa. Muharrom, Mukaromah, Dian, Ulfiah, dan Khomaeny (2019) menyatakan bahwa salah satu cara untuk membiasakan anak-anak hidup bersahaja ialah dengan cara mengajarkan memilah antara apa yang dibutuhkan dan apa yang tidak dibutuhkan serta mengajarkan menabung.

Usia sekolah dasar menjadi momen unggul untuk menanamkan budaya hidup sederhana dengan mengajak anak-anak untuk mempertimbangkan antara kebutuhan dan keinginan. Pada usia ini, anak-anak sudah dapat berhitung, mengenal uang dan transaksi sehingga dapat mulai diberi pemahaman tentang menabung dan berhemat sejak dini. Untuk itu, anak-anak dapat mulai diajari menghitung penerimaan dan pengeluaran uang jajan mereka pribadi agar mereka memahami arus masuk dan keluar uang. Mengajarkan pencatatan keuangan harian sederhana merupakan upaya menanamkan nilai-nilai akuntabilitas sejak dini kepada anak-anak. Dengan membuat catatan keuangan, anakanak dapat membuat gambaran secara mandiri bagaimana pengaturan keuangan dan bagaimana keuntungan yang diperoleh dengan menabungkan sebagian uang yang dimiliki. Permono (2013) menyatakan bahwa proses tumbuh kembang yang positif menjadi proses utama yang hakiki pada anak dan menjadi suatu hal yang amat penting. Proses tumbuh kembang dimulai dari saat pembuahan sampai pada usia sekolah dasar dan remaja. Keberhasilan tahun-tahun kecil si anak sebagian besar menentukan masa depan anak tersebut.

Oleh karena itu, orang dewasa dapat memgambil peranan penting untuk memberikan perlindungan dan kesejahteraan anak dengan memberikan hak-hak mendasar yang salah satunya melalui pendidikan karakter sejak dini. Upaya meminimalkan penyebaran budaya konsumtif dilakukan agar tidak berkelanjutan demi terwujudnya masa depan generasi bangsa yang lebih maju, cemerlang dan tidak kehilangan jati diri. Salah satu usaha mewujudkannya ialah melalui pendidikan kewirausahan kepada anak-anak. Jiwa wirausaha dalam arti luas sebagaimana dinyatakan oleh Fithriyana (2016) adalah bukan sekedar mengajarkan anak-anak mencari uang sejak dini, melainkan dengan tujuan untuk menumbuhkan karakter yang telah ada pada diri anak-anak. Maka, anak-anak sepatutnya diberikan literasi keuangan sejak dini. Literasi keuangan merupakan pengetahuan (knowledge), keyakinan (confidence), dan keterampilan ( $s k i l l$ ), yang dapat mempengaruhi sikap (attitude) dan perilaku (behaviour) untuk meningkatkan kualitas pengambilan keputusan dan pengelolaan keuangan dalam rangka mencapai kesejahteraan (Otoritas Jasa Keuangan, 2016).

Menurut Bakti, Sumanjaya, dan Nasution (2010), dari sudut pandang ekonomi makro, tabungan termasuk dalam kategori pendapatan rumah tangga yang tidak dikonsumsi dalam suatu periode tertentu. Tabungan adalah selisih antara pendapatan dengan konsumsi. Keynes (1936) menyatakan bahwa tabungan sama besarnya dengan investasi. Masyarakat perlu memahami pengelolaan keuangan khususnya untuk pengelolaan keuangan secara pribadi terlebih sebagai masyarakat yang tergolong konsumtif. Lestari dan Latifah (2019) menyatakan bahwa beberapa penelitian menunjukkan masih banyak mayarakat yang belum menyadari akan pentingnya pengelolaan keuangan khususnya untuk pengelolaan keuangan secara pribadi. Pengelolaan keuangan dengan cara baik dan terencana sangat bermanfaat untuk membantu terciptanya tujuan hidup yang lebih terarah. 
Program pengabdian masyarakat ini ditujukan untuk menumbuhkan kepedulian menabung bagi anak-anak di Desa Bonde, Kecamatan Pamboang, Kabupaten Majene dengan cara meningkatkan literasi keuangan. Target jangka panjang dari kegiatan ini adalah terciptanya masyarakat yang gemar menabung dan berkurangnya budaya hidup konsumtif pada masa anak-anak yang dilatih sudah dewasa.

\section{METODE}

Sasaran kegiatan ini adalah anak-anak pesisir Desa Bonde yang sudah mampu berhitung dan memahami penggunaan uang sebanyak 40 anak yang ada di 4 dusun yaitu Dusun Luaor, Soppeng Jawa, Tappa Banua dan Allealle. Sampel ditetapkan dengan menggunakan metode purposive sampling yaitu 10 anak sebagai utusan dari setiap dusun.

Tabel 1. Susunan acara pelatihan

\begin{tabular}{llll}
\hline Waktu & Kegiatan & Uraian & Pelaksana \\
\hline $13.00-14.00$ & Registrasi & Peserta melakukan registrasi & Aliya \\
$14.00-15.00$ & Pembukaan & Peserta mengikuti acara pembukaan & $\begin{array}{l}\text { MC : Urbanur } \\
\text { Do'a: Aparat Desa }\end{array}$ \\
$15.00-16.30$ & Materi & $\begin{array}{l}\text { Pelatihan pencatatan keuangan Sederhana dalam } \\
\text { upaya menumbuhkan kepedulian Menabung anak- } \\
\text { anak }\end{array}$ & Nurhidayah \\
$16.30-17.00$ & Penutup & Peserta mengikuti acara penutupan & MC : Urbanur \\
\hline
\end{tabular}

Pelatihan pencatatan keuangan sederhana untuk anak-anak pesisir dalam upaya menumbuhkan kepedulian mmenabung

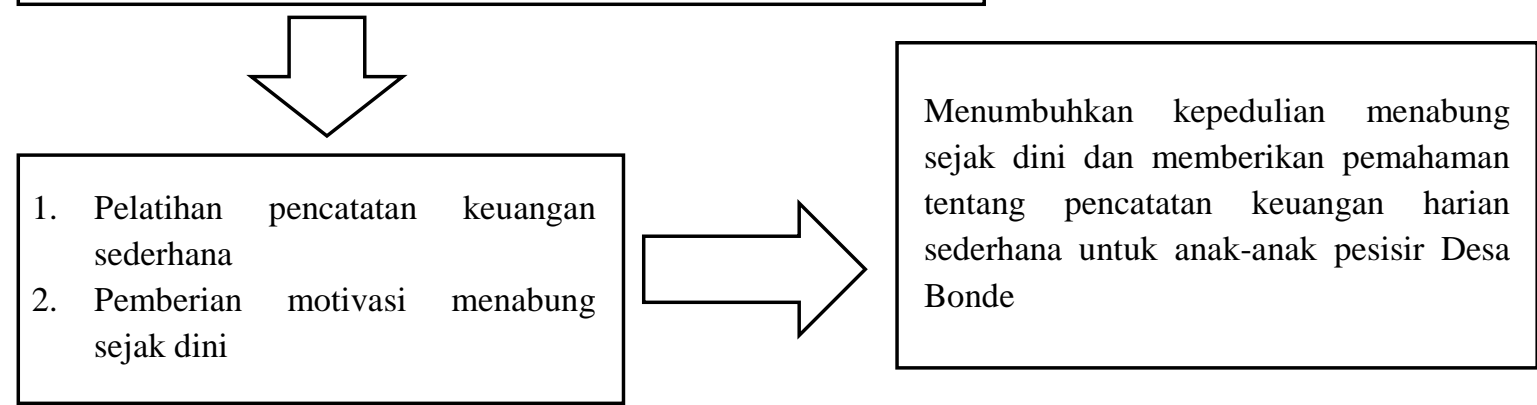

Menanamkan nilai Kejujuran dan memperkenalkan profesi Akuntan

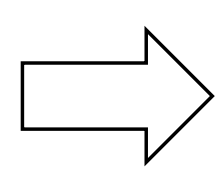

Simulasi \& Pendampingan
Anak-anak memperoleh pemahaman mengenai pencatatan keuangan sederhana dengan prinsip kejujuran dan memperkenalkan profesi akuntan kepada anak-anak

Anak-anak memperoleh pemahaman mengenai pencatatan keuangan sederhana dengan prinsip kejujuran dan memperkenalkan profesi akuntan kepada anak-anak

Gambar 1 Metode pelaksanaan kegiatan pengabdian kepada masyarakat 
Kegiatan pelatihan dilakukan pada hari Selasa, 20 Agustus 2019 yang bertempat di Aula Pertemuan Desa Bonde, Kecamatan Pamboang (Tabel 1). Pendampingan dilakukan sebagai kelanjutan dari kegiatan pelatihan sesuai dengan kerangka/bagan alur program pengabdian yang telah direncanakan (Gambar 1). Pendampingan dilakukan di salah satu rumah warga desa Bonde tepatnya di dusun Tappa Banua hingga bulan September 2019.

Metode ini didukung oleh penelitian Sirine dan Utami (2016) yang menyatakan bahwa pelaksanaan seminar/ pelatihan dapat dijadikan sebagai salah satu metode atau cara untuk meningkatkan pengetahuan tentang keuangan, sikap dan perilaku. Kemudian dapat dilakukan sosialisasi keuangan dengan mengundang pembicaraan dari kalangan orang tua untuk mengkomunikasikan masalah keuangan antara orang tua dan anak-anak.

\section{HASIL DAN PEMBAHASAN}

\section{Animo dan motivasi masyarakat mengikuti kegiatan}

Pelaksanaan kegiatan pelatihan pencatatan keuangan sederhana dimulai dengan melakukan registrasi. Hal ini menjadi kendala karena peserta merupakan anak-anak jenjang Sekolah Dasar kelas 4 sampai dengan kelas 6 yang masih lambat dalam menulis atau mengisi form registrasi dan baru belajar untuk membuat tandatangan. Panitia pelaksana mengambil inisiatif untuk menuliskan nama peserta kemudian ditandatangani oleh peserta. Peserta mendapatkan seminar kit dan modul pelatihan pencatatan keuangan sederhana untuk anak-anak yang akan dipakai pada saat pelatihan berlangsung. Animo masyarakat sangat tinggi terhadap kegiatan ini. Jumlah peserta yang hadir melampaui target awal. Peserta yang hadir berjumlah 43 orang anak dari 40 orang target. Dukungan dari masyarakat juga terlihat dari kehadiran orang tua anak dan guru-guru sekolah dasar yang ada di desa tersebut. Hal ini menandakan masyarakat Desa Bonde sangat antusias dengan kegiatan pelatihan pencatatan keuangan sederhana dalam upaya menumbuhkan kepedulian menabung anak-anak Desa Bonde.

Dukungan terhadap kegiatan ini juga ditunjukkan oleh pemerintah desa setempat. Hal ini ditunjukkan sejak awal berkoordinasi (Gambar 2). Kepala Desa, Sekertaris Desa dan beberapa staf desa juga hadir mengikuti kegiatan pelatihan. Kegiatan pelatihan diawali dengan acara pembukaan yang berlangsung selama 30 menit. Dalam sambutannya, Kepala Desa menyatakan dukungannya dan mengapresiasi kegiatan pelatihan ini dalam rangka menurunkan budaya konsumtif anak-anak di Desa Bonde. Koordinator Prodi Akuntansi Fakultas Ekonomi Universitas Sulawesi Barat mengharapkan anak-anak di Desa Bonde memiliki motivasi dan kepedulian menabung sejak dini untuk masa depan.

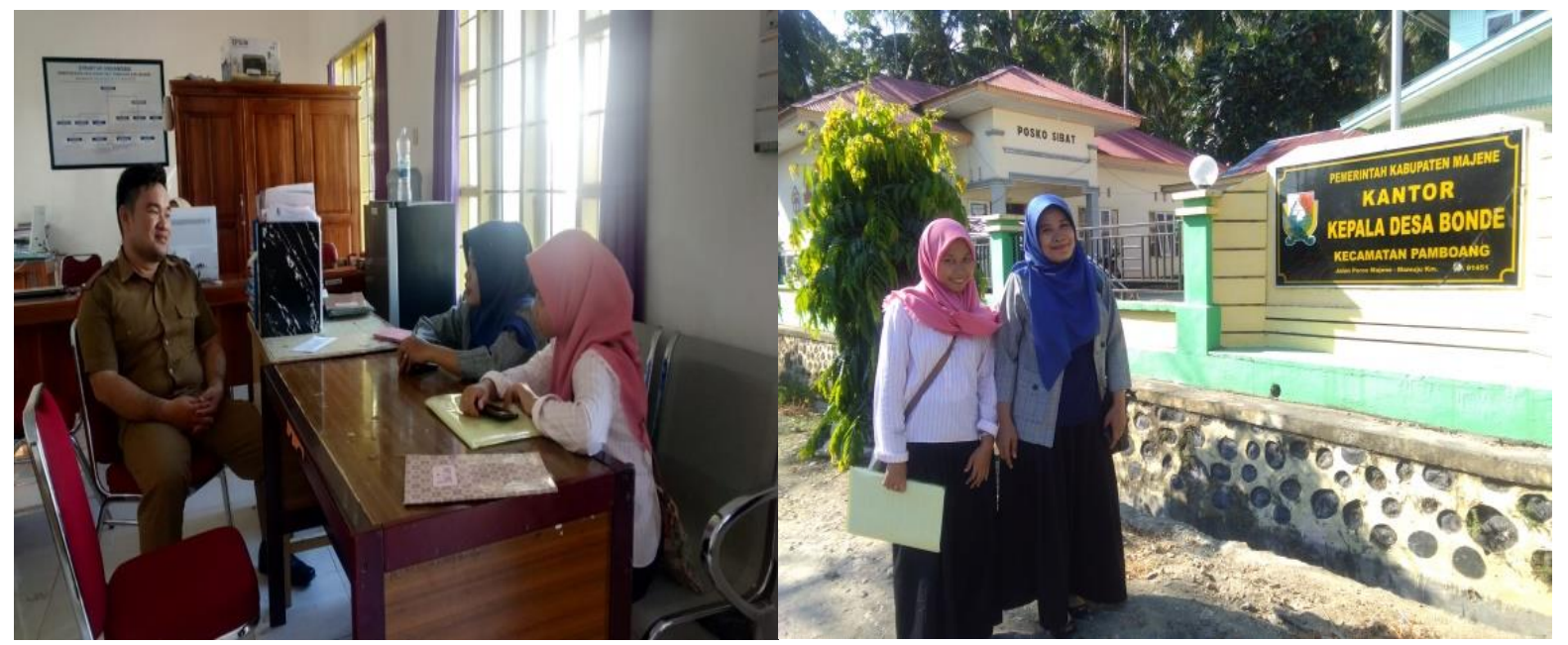

Gambar 2 Koordinasi dengan aparat Desa Bonde

Materi yang disampaikan pada pelatihan ini berkaitan dengan pengelolaan uang dengan tema utama adalah pencatatan keuangan sederhana. Sub-sub tema materi yang diberikan adalah uang, pencatatan keuangan harian sederhana untuk anak-anak, perbedaan kebutuhan dan keinginan, serta motivasi menabung sejak dini. Materi disampaikan dengan metode ceramah diselingi dengan permainan dan pemutaran beberapa video terkait pentingnya menabung. Setelah itu, peserta diajarkan praktek pencatatan keuangan sederhana melalui modul yang telah dibagikan sebelumnya. Praktek dilakukan dengan memberikan beberapa contoh transaksi sederhana yang biasanya dilakukan anak-anak sehari-hari. Disamping itu, peserta diberikan gambaran pertimbangan antara kebutuhan dan keinginan agar 
peserta memahami pentingnya menabung. Pelatihan pencatatan keuangan sederhana dalam upaya menumbuhkan kepedulian menabung berlangsung sesuai dengan rencana tanpa ada kendala yang begitu signifikan (Gambar 3).

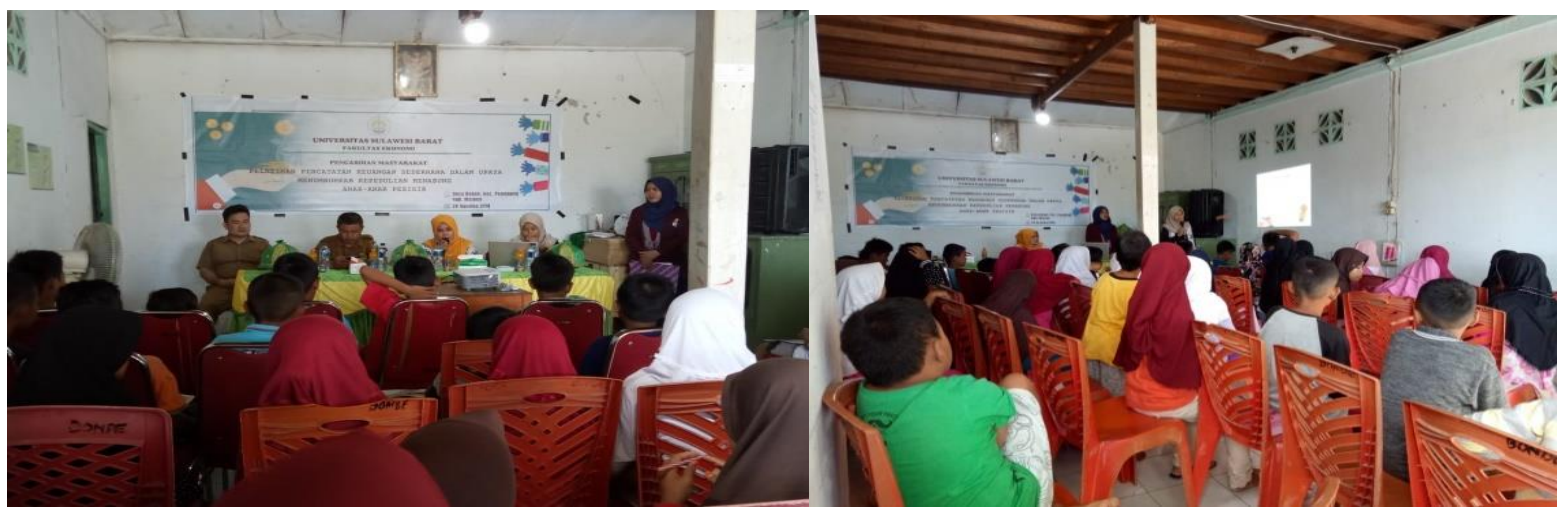

Gambar 3 Suasana pelatihan pencatatan keuangan sederhana dalam upaya menumbuhkan kepedulian menabung anak-anak Desa Bonde

Selama kegiatan, panitia mengamati dan mengevaluasi antusiasme peserta. Peserta menunjukkan antusias yang tinggi dan ikut serta pada setiap tugas dan kuis yang diberikan. Peserta terbaik diberikan penghargaan pada akhir materi. Seluruh peserta diberikan gift berupa celengan untuk lebih memotivasi kepedulian menabung peserta anakanak.

Kegiatan pelatihan dilanjutkan dengan kegiatan pendampingan. Hal ini dilakukan berdasarkan penjelasan Sina (2014) yang menyatakan bahwa penerapan pendidikan keuangan pada anak-anak sulit terlaksana jika tidak dilakukan secara disiplin dan berkesinambungan. Pendampingan dilakukan di salah satu rumah warga Desa Bonde yaitu di dusun Tappa Banua (Gambar 4). Meskipun hingga hari terakhir pendampingan tidak dihadiri 100\% oleh peserta anak-anak yang hadir pada hari pelatihan, tetapi persentase anak-anak yang hadir lebih banyak dari yang tidak hadir yaitu $80 \%$. Kegiatan pendampingan dilakukan di sore hari.

\section{Ketercapaian luaran kegiatan}

Pada saat pelaksanaan kegiatan pelatihan, anak-anak telah dibekali modul pencatatan keuangan sederhana yang wajib diisi sesuai dengan transaksi realita yang dilakukan sehari-hari. Catatan kembali dicek pada saat pendampingan. Sebanyak 75\% anak-anak sudah memahami tentang pencatatan keuangan harian sederhana. Mereka memiliki motivasi menabung dan sudah mulai menabung. Sebanyak 5\% masih belum memulai menabung meskipun sudah memahami catatan keuangan sederhana khususnya pemasukan dan pengeluaran. Sebanyak $20 \%$ lainnya tidak dapat digambarkan karna tidak menghadiri kegiatan pendampingan. Wawancara juga dilakukan terhadap orang tua peserta anak-anak untuk mengetahui perubahan-perubahan paska pelatihan. Secara umum, orang tua menjelaskan bahwa anak-anak sudah mulai peduli untuk menabungkan sebagian uang jajan yang biasanya diberikan harian sebelum berangkat sekolah. Tingkat keberhasilan dari program pengabdian melalui pelatihan dan pendampingan pencatatan keuangan sederhana dalam upaya menumbuhkan kepedulian menabung anak-anak Desa Bonde mencapai 82\%.

Dari hasil pendampingan juga dapat disimpulkan bahwa salah satu motivasi menabung ialah ilustrasi anakanak tentang masa depan. Pernyataan ini sependapat dengan penelitian Dakhi dan Lubis (2014) yang menyatakan bahwa masa depan menjadi faktor penting. Masa depan dapat mencakupi faktor-faktor lain yang dapat terjadi di masa mendatang. Selain motivasi dari dalam diri anak-anak sendiri, motivasi eksternal atau motivasi dari luar juga penting untuk anak-anak. Rizal, Maharani, dan Eliza (2016) menyatakan bahwa motivasi ekstrinsik ialah motivasi yang muncul dari luar diri pribadi seseorang. Salah satunya ialah pengaruh lingkungan yang melingkupi pergaulan dengan teman sebaya. Marwati (2018) menyarankan agar anak-anak perlu meperhatikan batasan-batasan baik buruk perilaku dalam bergaul dengan teman sebayanya. Oleh karena itu, menghindari pergaulan dengan teman sebaya yang dapat mengarahkan kepada perilaku hedonism dan budaya konsumtif yang tinggi juga diajarkan dalam pelatihan dan pendampingan.

Anak-anak pesisir Desa Bonde yang notabene adalah anak-anak nelayan diharapakan bisa mendorong tingkat ekonomi keluarga dengan perilaku menyisihkan sebagian uang jajan untuk ditabung. Menurut penelitian Rahmawati (2017), nelayan memiliki pendapatan harian yang tidak menentu. Masyarakat nelayan menggunakan pendapatannya untuk konsumsi harian dan pendidikan anak-anak. Sisa dari penggunaan konsumsi dan pendidikan dapat ditabung. Akan tetapi, jika pendapatan lebih sedikit dari konsumsi harian maka tidak ada yang dapat disisihkan untuk ditabung. 


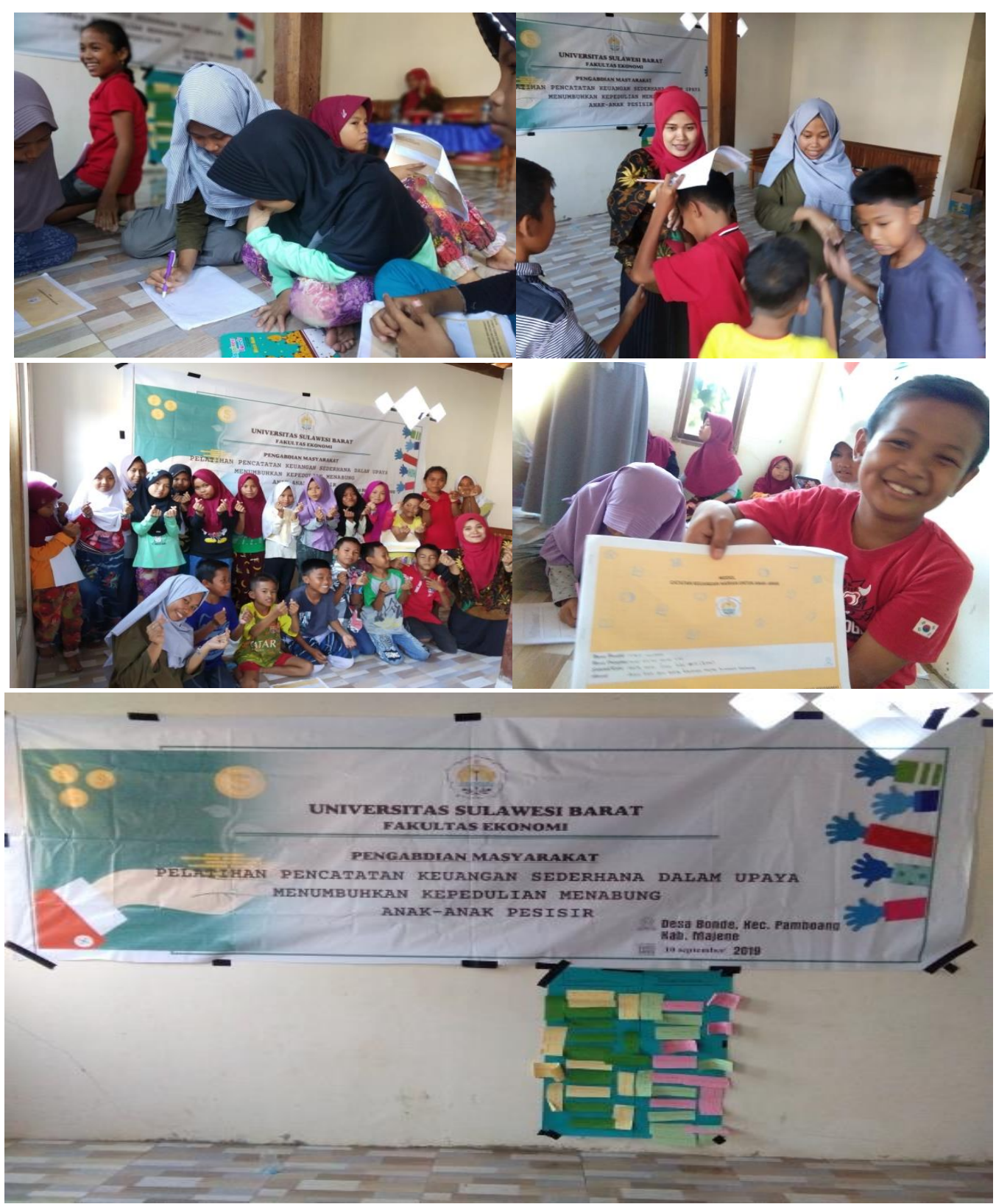

Gambar 4 Suasana pendampingan pencatatan keuangan sederhana dalam upaya menumbuhkan kepedulian menabung anak-anak Desa Bonde

Modul catatan keuangan sederhana untuk anak-anak menjadi salah satu motivasi anak-anak untuk menabung. Selain itu, modul ini bertujuan untuk melatih kejujuran anak-anak dengan mencatat pemasukan dan pengeluaran merekeka dengan sebenarnya berdasarkan bukti. Andarsari dan Dura (2018) dalam tulisannya mengemukakan bahwa pencatatan penerimaan dan pengeluaran harus sesuai dengan bukti transaksi yang terjadi dan telah dikumpulkan. Dengan adanya gerakan menabung dan catatan keuangan sederhana yang dilakukan oleh anak-anak Desa Bonde, orang tua terutama untuk ibu rumah tangga diharapkan juga dapat termotivasi dalam melakukan hal yang sama. Siska dan Sutrisno (2015) dalam penelitiannya mengemukakan bahwa motivasi menabung yang jarang dilakukan oleh ibu rumah tangga adalah motivasi catatan pengeluaran dan motivasi penilaian ulang tujuan penyimpan dana. Sedangkan motivasi menabung yang tidak pernah dilakukan ibu rumah tangga adalah motivasi pemotongan pengeluaran, mempertimbangkan prioritas dan menghentikan penggunaan kartu kredit.

\section{KESIMPULAN}

Pemahaman mengenai kebutuhan dan keinginan yang disertai dengan pencatatan keuangan harian dapat menumbuhkan perilaku menabung bagi anak-anak. Sebanyak $70 \%$ anak-anak Desa Bonde sudah memahami tentang 
pencatatan keuangan sederhana untuk transaksi harian yang biasa dilakukan dan sudah memulai untuk menabungkan sebagian uang jajan yang diberikan oleh orang tua/wali setelah mengikuti pelatihan dan pendampingan. Sebagian lainnya ada yang sudah memahami namun belum termotivasi untuk menabung sejak dini.

Batasan kegiatan pendampingan adalah hanya pada pencatatan atau pengisian modul pencatatan keuangan sederhana sehingga tidak dapat dilakukan pendampingan setiap hari. Maka, hasil yang lebih baik akan diperoleh jika orang tua/wali juga berperan aktif dalam memotivasi kepedulian menabung anak-anak sejak dini. Jika kegiatan pendampingan dilakukan secara lebih intens kepada peserta yang dalam hal ini adalah kalangan anak-anak, target pencapaian kegiatan pengabdian dapat lebih baik.

\section{UCAPAN TERIMA KASIH}

Kegiatan pengabdian kepada masyarakat ini didanai oleh Hibah Daftar Isian Pelaksanaan Anggaran Perguruan Tinggi Universitas Sulawesi Barat melalui Lembaga Penelitian dan Pengabdian pada Masyarakat dengan Surat Perjanjian T/155/UN55.C/KP.00.05/2019.

\section{DAFTAR PUSTAKA}

Andarsari, P. R., \& Dura, J. (2018). Implementasi pencatatan keuangan pada usaha kecil dan menengah. Jurnal Ilmiah Bisnis dan Ekonomi Asia, 12(1), 59-65.

Anggreini, R., \& Mariyanti, S. (2014). Hubungan antara kontrol diri dan perilaku konsumtif mahasiswi Universitas Esa Unggul. Jurnal Psikologi, 12(1), 34-42.

Badan Pusat Statistik Kabupaten Majene. (2018). Kabupaten Majene dalam Angka. Majene, Indonesia: Badan Pusat Statistik Kabupaten Majene.

Bakti, T. D., Sumanjaya, R., \& Nasution, S. H. (2010). Pengantar ekonomi makro. Medan, Indonesia: USU Press.

Dakhi, A. S., \& Lubis, I. (2014). Analisis minat menabung di kalangan siswa SMA Negeri di Kota Medan. Jurnal Ekonomi dan Keuangan, 2(9), 525-534.

Fithriyana, R. (2016). Peningkatan kewirausahaan melalui pembelajaran dengan menggunakan media budidaya pada anak usia dini di TK Taqifa Bangkinang Kota Tahun 2016. Jurnal Obsesi : Jurnal Pendidikan Anak Usia Dini, 2(2), 125-135.

Keynes, J. M. (1936). The general theory of employment, interest, and money. Macmillan, England: Palgrave Macmillan.

Lestari, C. T., \& Latifah, F. (2019). Aplikasi pencatatan keuangan pribadi dengan analisa SWOT menggunakan algoritma sequential search berbasis mobile. JISAMAR (Journal of Information System, Applied, Management, Accounting and Researh), 3(2), 11-18.

Marwati, R. D. (2018). Faktor-faktor yang mempengaruhi perilaku menabung mahasiswa S1 Fakultas Ekonomi Universitas Negeri Yogyakarta. Jurnal Pendidikan Ekonomi: Kajian Ilmiah Bidang Pendidikan dan Ekonomi, $7(5), 476-487$.

Muharrom, G. M., Mukaromah, G. N., Dian, H. A., Ulfiah, N. S., \& Khomaeny, E. F. F. (2019). Menanamkan sikap bersahaja pada anak usia dini dengan pembiasaan menabung. Early Childhood: Jurnal Pendidikan, 3(1), 5867.

Otoritas Jasa Keuangan. Peraturan Otoritas Jasa Keuangan Nomor 76 /POJK.07/2016 Tentang peningkatan literasi dan inklusi keuangan di sektor jasa keuangan bagi konsumen dan/atau masyarakat, Pub. L. No. 76 /POJK.07/2016 (2016). Indonesia.

Permono, H. (2013). Peran orangtua dalam optimalisasi tumbuh kembang anak untuk membangun karakter anak usia dini. Di dalam Prosiding Seminar Nasional Psikologi Parenting Optimalisasi Peran Orangtua dalam Pendidikan Karakter Bangsa (hal. 34-47). Surakarta, Indonesia: Fakultas Psikologi Universitas Muhammadiah Surakarta.

Rahmawati, N. (2017). Pengaruh pendapatan terhadap tabungan pada masyarakat nelayan di Desa Kuala Secapah Kecamatan Mempawah Hilir [Skripsi]. Universitas Tanjungpura.

Rizal, R., Maharani, E., \& Eliza, E. (2016). Analisis motivasi ekstrinsik petani dalam menabung di Bank Rakyat Indonesia (BRI) Unit Ukui Kecamatan Ukui Kabupaten Pelalawan. Jurnal Ilmiah Pertanian, 13(1), 15-21. 
Sina, P. G. (2014). Peran orang tua dalam mendidik keuangan pada anak (Kajian Pustaka). Ragam Jurnal Pengembangan Humaniora, 14(1), 74-86.

Sirine, H., \& Utami, D. S. (2016). Faktor-faktor yang memengaruhi perilaku menabung di kalangan mahasiswa. Jurnal Ekonomi dan Bisnis, 18(1), 27.

Siska, O. D., \& Sutrisno, D. (2015). Analisis motivasi menabung ibu rumah tangga di Kelurahan Kebonsari Kecamatan Sumbersari Kabupaten Jember. Jurnal Pendidikan Ekonomi: Jurnal Ilmiah Ilmu Pendidikan, Ilmu Ekonomi dan Ilmu Sosial (JPE), 9(1), 47-55. 